\title{
ДЕЯКІ ПИТАННЯ ІМПЛЕМЕНТАЦІЇ РИМСЬКОГО СТАТУТУ МІЖНАРОДНОГО КРИМІНАЛЬНОГО СУДУ У ЗАКОНОДАВСТВО ДЕРЖАВ-ЧЛЕНІВ
}

Пилипенко В. П.

у статmі досліджуються актуальні питання імплементації положень Римського статуту Міжнародного кримінального суду щодо воєнних злочинів у законодавство деяких держав-учасниць Римського статуту. Міжнародна спільнота давно намагається створити постійно чинну міжнародну судову систему з метою притягнути до відповідальності осіб, винних у найтяжчих злочинах, таких як геноцид, агресія, злочини проти людства й воєнні злочини. Стверджується, що головним завданням Міжнародного кримінального суду є здійснення міжнародного правосуддя щодо осіб, яких звинувачують у вчиненні найтяжчих міжнародних злочинів. У преамбулі його Cmamymу підкреслюється, що Суд пов'язаний із системою ООН і має юрисдикцію щодо найтяжчих злочинів, що викликають занепокоєння всієі міжнародної спільноти. Метою сmammi $є$ вивчення особливостей у процесі імплементації положень Статуту Міжнародного кримінального суду в законодавство деяких іноземних держав-членів Cmaтуту. Стверджується, що найпоширенішими способами імплементації міжнародного права в національну правову систему є рецепція, тобто текстове повторення нормотворчим органом держави змісту міжнародного права в статті нормативного правового акта; трансформація, що означає обробку тексту міжнародно-правового акта або окремих його статей із прийняттям на цій основі внутрішнього законодавства; посилання, що є вказівкою у внутрішньому правовому акті міжнародного права як джерела, що регулює ці довідкові відносини. Доводиться теза про те, що підписання та ратифікація Римського статуту накладає на держави, що приєдналися, зобов'язання привести своє національне законодавство й правозастосовну практику відповідно до положень Cтатуту. Так, у законодавстві держави-учасниці повинні отримати закріплення принцип компліментарності юрисдикції Суду щодо юрисдикції національних судів і принцип неприпустимості посилання на посадове становище особи для звільнення їі від відповідальності. Констатується, що параметри сприйняття положень Римського cmamymy в контексті покарання за воєнні злочини визначаються самою державою в ії внутрішньому законодавстві з урахуванням типу їі правової системи, конституційних положень, а також міжнародно-правових зобов'язань держави.

Ключові слова: Римський статут Міжнародного кримінального суду, Міжнародний кримінальний суд, імплементація, трансформація, воєнні злочини, кримінальне законодавство, принцип компліментарHOCMi.

Pylypenko V. P. Some issues of the Rome Statute of the International Criminal Court implementation into the legislation of the member states

Current issues of implementation of the International Criminal Court Statute provisions on war crimes in the legislation of some member states of the Rome Statute are examined in the article. The international community has long sought to establish a permanent international judiciary to bring to justice those responsible for the most serious crimes, such as genocide, aggression, crimes against humanity and war crimes. It is argued that the main task of the International Criminal Court is to administer international justice to persons accused of committing the most serious international crimes. The preamble to its Statute emphasizes that the Court is linked to the UN system and has jurisdiction over the most serious crimes of concern to the entire international community. The purpose of this article is to explore the features and issues in the process of implementing the provisions of the Statute of the International Criminal Court in the legislation of some foreign member states of the Statute. It is argued that the most common ways of implementing international law into the national legal system are reception, ie textual repetition by the rule-making body of the state of the content of the international law in the article of the normative legal act; transformation, which means the processing of the text of an international legal act or its individual articles with the adoption on this basis of domestic law; reference, which is an indication in a domestic legal act of international law as a source governing these reference relations.

It is argued that the signing and ratification of the Rome Statute imposes an obligation on the acceding states to bring their national legislation and law enforcement practices into line with the provisions of the Statute.

(С Пилипенко В. П., 2020 
Thus, member-states shell enshrine in law the principle of complementarity of the Court jurisdiction in relation to the jurisdiction of national courts and the principle of the inadmissibility of a reference to a person's official position in order to release him or her from liability. It is stated that the parameters of perception of the Rome Statute provisions on punishments for war crimes are determined by the state itself in its domestic legislation, taking into account the type of its legal system, constitutional provisions and international legal obligations of the state.

Key words: Rome Statute, Statute of the International Criminal Court, International Criminal Court, implementation, transformation, war crimes, criminal law, principle of complementarity.

Постановка проблеми та іï актуальність. Міжнародна спільнота давно прагнула до створення постійно чинного міжнародного судового органу, покликаного притягати до відповідальності осіб, які винні в скоєнні найтяжчих злочинів, таких як геноцид, агресія, злочини проти людяності, воєнні злочини. Людству довелося пережити трагедії двох світових воєн, геноцид в Югославії та Руанді, щоб прийти до усвідомленого й узгодженого рішення створити перший в історії постійно чинний Міжнародний кримінальний суд (далі - МКС, Суд). На Дипломатичній конференції повноважних представників, що проходила під егідою ООН у Римі, 17 липня 1998 р. був прийнятий Статут Міжнародного кримінального суду [20] (далі - Статут МКС). Основне завдання МКС полягає в здійсненні міжнародного правосуддя над особами, обвинувачуваними в скоєнні найтяжчих міжнародних злочинів. У преамбулі Статуту підкреслюється, що Суд пов'язаний із системою ООН і має юрисдикцію щодо найтяжчих злочинів, які викликають занепокоєння всієї міжнародної спільноти. Приєднання держави до Статуту МКС тягне за собою істотні наслідки для ії правової системи. 3 урахуванням того, що ратифікація Статуту МКС накладає на відповідні держави зобов'язання привести своє національне законодавство й правозастосовну практику відповідно до положень Статуту, в законодавстві держав-учасниць мають отримати закріплення принцип компліментарності юрисдикції МКС щодо юрисдикції національних судів і принцип неприпустимості посилання на посадове становище особи для звільнення іï від відповідальності. Крім того, держава зобов'язана вжити заходів, що забезпечують взаємодію з МКС і гарантують передачу Суду осіб, обвинувачених у вчиненні злочинів, та участь у фінансуванні діяльності МКС. Понад 120 держав світу наразі ратифікували або приєднались до Статуту МКС. Законодавство щодо імплементації положень Статуту МКС прийняло близько 40 держав, у тому числі Австралія, Аргентина, Бельгія, Великобританія, Німеччина, Грузія, Іспанія, Канада, Литва, Мальта, Нідерланди, Нова Зеландія, Португалія, Уругвай, Фінляндія, Швейцарія, Південно-Африканська Республіка й низка інших держав. Ще кілька десятків держав, які ратифікували Статут МКС, знаходиться в процесі розробки й прийняття необхідних для імплементації актів [13, с. 76]. 3 огляду на зазначене вище, видається актуальним і необхідним дослідити особливості механізму імплементації положень Статуту МКС у законодавство держав - учасниць Римського Статуту.

Аналіз останніх публікацій i досліджень. Питання створення, функціонування та імплементації положень Статуту МКС досліджувались такими вітчизняними вченими, як: В.Ф. Антипенко, В.А. Базов, М.В. Буроменський, В.Г. Буткевич, М.М. Гнатовський, Н.В. Дрьоміна, С.О. Загороднюк, Н.А. Зелінська, О.В. Касинюк, А.О. Кориневич, Г.Л. Кохан, І.О. Колотуха, В.М. Лисик, А.С. Мацко, А.А. Маєвська, В.М. Репецький, В.П. Попович, М.І. Хавронюк, О.Р. Фісенко, В.Х. Ярмакі й інші.

Метою статті $\epsilon$ дослідити особливості й проблемні питання в процесі імплементації положень Статуту Міжнародного кримінального суду в законодавство деяких держав - учасниць Римського Статуту.

Виклад основного матеріалу. Держави, як це випливає зі змісту відповідних норм чинного міжнародного права й підтверджується правозастосовчою практикою, мають основні зобов'язання у зв'язку із забезпеченням кримінального переслідування та покарання осіб, які вчинили воєнні злочини. У зв'язку із цим особливого значення набуває питання криміналізації в національному кримінальному законодавстві серйозних порушень норм міжнародного гуманітарного права (далі МГП), що застосовується в збройних конфліктах. Міжнародно-правові акти, що діють у такій сфері, покладають на держав-учасниць зобов'язання криміналізувати такого роду серйозні порушення МГП і передбачити ї кримінальну відповідальність, беручи до уваги їх міжнародну й суспільну небезпеку.

Як зазначає С.А. Лобанов, «в цілому йдеться про два взаємопов'язані фактори, що лежать в основі такого процесу. По-перше, слід враховувати вплив міжнародного права, що має пріоритет у питанні криміналізації такого роду діянь 
(як злочинів проти миру й безпеки людства). У спеціальній літературі [1, с. 175-176] обґрунтовано зазначається, що норми внутрішньодержавного права не можуть суперечити міжнародному праву, мало того, повинні забезпечувати реалізацію вимог міжнародно-правових норм, обов'язкових для такої держави'. I в такому зв'язку підхід до криміналізації аналізованих діянь і заходів покарання за них повинен відповідати вимогам міжнародного кримінального права. По-друге, параметри сприйняття положень міжнародного кримінального права визначаються самою державою з урахуванням типу їі правової системи, конституційних положень, що діють у ній, а також iii міжнародно-правових зобов'язань у зв'язку з участю в міжнародних договорах» [12, с. 267]. Причому тут слід враховувати не тільки специфіку континентальних правових традицій і традицій загального права, а й національно-правові особливості, регіональний фактор. Так, можна вести мову про певну подібність кримінально-правових систем держав Співдружності Незалежних Держав, а також і інших інтеграційних об'єднань, що, звичайно, не виключає відмінностей, іноді досить істотних, у підході криміналізації воєнних злочинів у кримінальному законодавстві держав. Не випадково Міжнародний комітет Червоного Хреста (далі - МКЧХ) у ході роботи щодо організації та координації дій держав у рамках виконання ними зобов' язань щодо імплементації МГП (яке, як підкреслюється МКЧХ, у цілому повинно бути універсальним, оскільки його метою $є$ захист жертв збройних конфліктів) запропонував розробляти поряд з іншими документами типові закони, що орієнтовані на прийняття імплементаційних заходів з урахуванням регіональних рамок або подібності правових систем відповідних груп держав [5, с. 83]. Щодо конкретного способу виконання такого зобов'язання, техніки законодавчого опису діянь, що криміналізуються, заходів і видів покарань, то тут держава має вибір. Зарубіжні вчені, досліджуючи проблеми національно-правової імплементації у зв'язку з участю держав у Статуті МКС, відзначають, що фактично національні системи зберігають автономію свого кримінального права навіть після вступу Статуту МКС у чинність для них, оскільки нормативний стандарт, перед-

1 Таке розуміння повною мірою узгоджується з нормами чинного міжнародного права. Зокрема, в ст. 27 Віденської конвенції про право міжнародних договорів від 23 травня 1963 р. закріплено положення, згідно з яким держава - учасниця договору не може посилатися на положення свого внутрішнього права як на виправдання невиконання нею договору. 3 проблеми виконання міжнародних договорів у контексті принципу добросовісності див., наприклад: [9, с. 168-210]. бачений Статутом, полягає в бажанні й здатності держави здійснювати кримінальне переслідування (ст. 17 Статуту МКС), та у зв'язку із цим деяка відмінність формулювань складів злочинів у національному праві від відповідних визначень, що містяться в Статуті МКС, самі по собі не можуть бути перешкодами для здійснення державою кримінального переслідування [2, с. 161].

Кримінальний закон держави може містити вказівку на можливість прямого відсилання до норми міжнародного права під час розв'язання кримінально-правових питань, у тому числі у зв'язку з криміналізацією воєнних злочинів. Крім того, приведення норм національного кримінального закону в питаннях злочинності й караності діяння відповідно до вимог міжнародного права за загальним правилом здійснюється за допомогою сприйняття нормами національно-правової системи приписів системи міжнародноправової. Своєю чергою, як зазначається в юридичній літературі, таке сприйняття може бути проведено трьома способами: 1) текстуального включення норми міжнародного кримінального права в кримінальне законодавство на виконання міжнародного договору; 2) включення норми міжнародного кримінального права в кримінальне законодавство, причому припис міжнародного договору не встановлює жорсткої форми сприйняття його приписів у внутрішньодержавному праві; 3) зміни вже наявних норм кримінального законодавства на виконання положень міжнародного кримінального права [11, с. 187-188]. Крім того, з певною часткою узагальнення можна вести мову про такі два (поряд із прямим відсиланням) основні способи впливу міжнародного права на національне кримінальне законодавство: рецепція - акт міжнародного права як джерело кримінального права повністю включається в кримінальний закон без будь-яких змін, водночас може вводитися нова норма або змінюватися наявна; імплементація - вже наявна кримінально-правова норма або (частіше) вводиться нова норма кримінального закону, що адаптується внутрішнім законодавцем на виконання міжнародного договору [10, с. 192-193]. Як показує практика, держави використовують вищезгадані варіанти й водночас нерідко їх поєднують. Насамперед слід відзначити, що вітчизняна юридична література неоднозначно називає процес узгодження норм внутрішньодержавного й міжнародного права. Найчастіше пропонуються такі терміни: «рецепція», «трансформація», «національно-правова імплементація» або просто «імплементація», 
«здійснення» (реалізація), «застосування», «виконання». Майже всі автори розуміють під такими найменуваннями механізм здійснення (реалізації) норм міжнародного права. У міжнародному праві для позначення поняття «здійснення» норм міжнародного права широкого поширення набула юридична конструкція «імплементація норм міжнародного права». У Словнику міжнародно-правових термінів термін «імплементація» (від лат. implere - наповнювати, досягати, виконувати, здійснювати) в міжнародному праві розуміється як організаційно-правова діяльність держав із метою реалізації своїх міжнародно-правових зобов'язань [4, с. 184]. Термін «імплементація» буквально означає «втілення в життя відповідно до певної процедури» [27, р. 667], «забезпечення практичного результату й фактичного виконання конкретними засобами» [36, р. 1134]. Термін набув широкого поширення в численних резолюціях Генеральної Асамблеї ООН та її органів, у багатьох міжнародних конвенціях та інших міжнародноправових актах. Значного поширення в міжнародно-правовій літературі набули також вирази «механізм імплементації», «імплементаційні статті». Водночас під механізмом імплементації розуміють передбачену міжнародним договором систему заходів контролю за його виконанням або певні органи, створені із цією метою міжнародним договором, і процедуру їх роботи. Поняття «імплементаційні статті» означає ті статті договору, що передбачають систему заходів для реалізації договору. У довідковій літературі можна зустріти такі визначення терміну: «імплементація в широкому сенсі слова означає здійснення міжнародно-правових і внутрішньодержавних норм на виконання міжнародно-правових, а також створення на міжнародному й внутрішньодержавному рівнях умов для такого здійснення» [21, с. 102]. Під «імплементацією А.С. Гавердовський розуміє цілеспрямовану організаційно-правову діяльність держав, що здійснюється індивідуально, колективно або в рамках міжнародних організацій із метою своєчасної, всебічної та повної реалізації прийнятих ними відповідно до міжнародного права зобов'язань [3, с. 62]. Це визначення видається найповнішим, оскільки його очевидна перевага полягає в тому, що тут зафіксований підхід до процесу реалізації міжнародного права як до органічного поєднання правотворчої та організаційної діяльності держав, що здійснюється ними всередині держави й на міжнародній арені, в тому числі за допомогою та в рамках наявних або знов створюваних інституційних структур. Отже, про імплементацію міжнародно-правових норм можна говорити тільки в тому випадку, якщо держава не тільки видає відповідні законодавчі акти (змінює чи скасовує вже наявні) для здійснення норм міжнародного права, а й проводить в життя ці акти. Тому національно-правова імплементація норм міжнародного права - це тільки етап у процесі їх імплементації (здійснення), вона створює лише юридичні передумови для їх виконання. Отже, найпоширенішими способами імплементації міжнародно-правових норм у національну систему права $\epsilon:$ 1) рецепція, тобто текстуальне повторення нормотворчим органом держави змісту міжнародно-правової норми в статті нормативно-правового акта; 2) трансформація, під якою розуміється перероблення тексту міжнародноправового акта чи окремих його статей із прийняттям на цій основі норм внутрішнього права; 3) відсилання, яке являє собою вказівку у внутрішньодержавному нормативно-правовому акті на міжнародне право як на джерело, що регулює ці відсильні відносини. Як зазначається в міжнародно-правовій літературі, під час розв'язання питання про відповідність Статуту МКС Конституції та іншим законодавчим актам необхідно виходити з того, що він - не відірвана від сучасних правових реалій інституція, а ії частина, яку необхідно тлумачити з урахуванням положень міжнародного кримінального права, що розвивається. Традиційна концепція щодо участі чи неучасті держав у міжнародних угодах на основі їх суверенних прав незастосовна до Римського статуту, оскільки його цілі й об'єкт регулювання склалися під впливом імперативних норм сучасного міжнародного права (jus cogens) [23, с. 123].

Так, у Посібнику для ратифікації та імплементації Римського Статуту [17] вказується, що достатніми для приведення законодавства країни відповідно до положень Статуту МКС $є$ такі заходи: 1) прийняття визначення, яке повністю відтворює текст відповідної статті Статуту чи містить пряме відсилання до нього; 2) передбачення окремих складів злочинів для кожного з діянь, згаданих у Статуті. Можливо певною мірою змінити визначення відповідного злочину, але зі збереженням аналогічного зі Статутом змісту або ж із його розширенням, щоб гарантовано не давати можливості винним уникнути відповідальності; 3) можливість держав притягувати до кримінальної відповідальності на основі загальнокримінальних складів злочинів. Одним зі способів тут називається застосування наявних у національному законодавстві складів злочинів, подібних за змістом, якщо не за формою, до 
складів злочинів, закріплених у Статуті. Держави можуть переслідувати за діяння, яке прирівнюється до визначених у Статуті злочинів, використовуючи досить серйозні національні склади злочинів. Це давало б підстави для тверджень, що відповідний злочин вчинено (такий підхід характерний для Данії та Норвегіï) [17]. Така можливість передбачається у вказаному вище Посібнику, проте тут зазначається і те, що справа підпадатиме під провадження МКС, зокрема, якщо національні принципи індивідуальної кримінальної відповідальності, підстави для виключення кримінальної відповідальності або застосовувані покарання суттєво відрізняються від передбачених Статутом. Останнє положення, на нашу думку, автоматично виключає застосування державами складів загальнокримінальних злочинів як підстави для притягнення до відповідальності осіб за діяння, що утворюють склади злочинів, закріплені в Статуті [17]. В іншому документі зазначається, що національний закон, в якому криміналізовано певне діяння, навряд чи буде достатнім для цілей включення злочинів, відповідальність за які передбачена в Статуті, в національний закон. Такий звичайний злочин, як вбивство, не однаковий зі злочином проти людяності чи воєнним злочином, що вчинені шляхом вбивства, оскільки відсутня необхідна мета, через що перший не проходить межового критерію міжнародних злочинів [17]. Деякі держави (наприклад, США, Великобританія, Канада, Нідерланди, Швеція, Швейцарія), застосовують імплементаційне законодавство, передбачаючи злочин у національному праві. Окремі держави покладаються на пряму застосовність міжнародного права в національній системі права. Інші ж держави лише застосовують аналогічні національні злочини. Крім того, зауважимо, що під час визначення конкретних способів, якими держава може скористатися для приведення національного законодавства відповідно до Статуту МКС, вкрай важливим і корисним є ознайомлення з положеннями деяких міжнародних документів, розроблених міжнародними організаціями з метою сприяти приєднанню та пришвидшити процес узгодження національних законів держав зі Статутом МКС. До таких, зокрема, належать: Керівні Принципи для ефективної імплементації Римського Статуту [28]; Контрольний список для імплементації Римського Статуту [32]; Нездатність держав ефективно імплементувати Римський Статут [30]; 14 принципів для ефективного здійснення універсальної юрисдикції [33]; Універсальна юрисдикція: обов'язок держав встановити й імплементувати законодавство [34]; Посібник з імплементації та ратифікації [17]; Парла- ментський Пакет документів із Міжнародного кримінального суду [16]; Керівництво з імплементації та ратифікації Римського Статуту [29]; Довідник з імплементації Римського Статуту [31] та інші.

Отже, проаналізуємо законодавство деяких держав - учасниць Статуту МКС у контексті закріплення складів воєнних злочинів у національному законодавстві.

Видається, що в такому сенсі найцікавішим $\epsilon$ досвід тих зарубіжних держав, які безпосередньо зіткнулися з вчиненням воєнних злочинів їх громадянами й (або) на їх територіях. Очевидно, найяскравішим прикладом розвитку національного законодавства щодо воєнних злочинів на основі міжнародного кримінального права $€$ прийняття у Федеральній Республіці Німеччині (далі ФРН) Кодексу міжнародного кримінального права (далі - Кодекс ФРН), введеного в дію 26 червня 2002 року ("Volkerstrafgesetzbuch" - VStGB) [35]. Кодекс ФРН складається з Загальної та Особливої частин. У Загальній частині закріплюється принцип універсальної юрисдикції, особливу обставину, що виключає винність (це наказ або розпорядження), встановлюються норми щодо командної відповідальності й незастосування строків давності. Особлива частина кодексу встановлює відповідальність за геноцид (ст. 6), злочини проти людяності (ст. 7), воєнні злочини (ст. ст. 8-12) і інші, пов'язані з міжнародними злочини (ст. ст. 13-14). У ст. 8 Кодексу закріплена відповідальність за воєнні злочини щодо фізичних осіб. Ст. 9 Кодексу ФРН впроваджує кримінальну відповідальність за воєнні злочини проти власності й інших прав. Крім того, ст. 10 такого акту встановлює кримінальну відповідальність за воєнні злочини проти гуманітарних операцій і за незаконне використання розпізнавальних емблем Женевських конвенцій, ООН та інших, якщо це спричинило заподіяння смерті або шкоди здоров'ю людини. Ст. ст. 11 і 12 Кодексу ФРН регламентують відповідальність за воєнні злочини, що пов'язані з використанням заборонених міжнародним правом засобів і методів ведення воєнних дій. Ст. 12 Кодексу ФРН прямо перераховує деякі з видів забороненої зброї, застосування яких тягне за собою кримінальну відповідальність. Слід зазначити, що після довгого періоду відсутності практики застосування Кодексу Вищий земельний суд у Штутгарті 28 вересня 2015 року на підставі Кодексу міжнародного кримінального права ФРН 2002 року засудив двох лідерів Демократичних сил звільнення Руанди Ігнаса Мурваначьяку й Стратона Мусон до реальних термінів 
позбавлення волі за керівництво терористичною організацією та пособництво у вчиненні воєнних злочинів [6].

Іншим прикладом приведення національного законодавства щодо воєнних злочинів відповідно до міжнародного кримінального права $\epsilon$ Хорватія, на території якої відбувалося кілька збройних конфліктів, у тому числі міжнародного характеру. У Кримінальному кодексі (далі - КК) Республіки Хорватія [22] закріплений значний перелік воєнних злочинів проти цивільних осіб, що здійснюються під час війни, збройного конфлікту або окупації (ст. ст. 158-168). Крім того, КК Хорватії як самостійний склад злочину розглядає «організацію групи або підбурювання до геноциду або воєнним злочинам» (ст. 123), «планування злочинів проти цінностей, що знаходяться під захистом міжнародного права» (ст. 187a), а також «допомогу особі, яка вчинила злочин проти цінностей, що знаходяться під захистом міжнародного права» (ст. 187b). Положення КК Хорватії про воєнні злочини активно застосовуються на практиці. Справи про військові злочини в Республіці Хорватія в першій інстанції розглядаються тільки окружними судами, які розташовані в Загребі, Спліті, Рієці, Осієку. Наразі в різних судах на стадії розгляду знаходиться 18 кримінальних справ про воєнні злочини [7]. Таким чином, з урахуванням наведеного вище аналізу законодавства Німеччини й Хорватії можна дійти висновку, що ці держави демонструють нам два технічно різні способи зміни національного законодавства про воєнні злочини з метою виконання взятих на себе міжнародних зобов'язань. Звісно ж, що зарубіжний досвід може бути корисним у процесі вдосконалення та усунення прогалин у законодавчій регламентації інституту воєнних злочинів у вітчизняному кримінальному законодавстві.

Висновки. Отже, на підставі аналізу законодавства деяких держав - учасниць Римського Статуту в контексті імплементаціі його положень в їх внутрішньодержавне законодавство ми дійшли таких висновків. По-перше, кожна держава-учасниця Статуту МКС $\epsilon$ вільною у виборі шляхів імплементації своїх договірних зобов'язань до тих пір, поки вона діє добросовісно й результат цих дій свідчить про здатність виконати всі зобов'язання за Статутом МКС. По-друге, в процесі імплементації Статуту МКС державам-учасницям доводиться розв'язувати три основні блоки питань: 1) усунення суперечностей між Статутом МКС і конституційними актами держави; 2) приведення національного кримінального законодавства відповідно до вимог Статуту МКС; 3) створення правової бази взаємодії з МКС.
Як показує вже наявна практика процесу імплементації, кожне із зазначених вище завдань може розв'язуватися різними шляхами, виходячи з правових традицій конкретної держави або навіть простого розсуду законодавця. По-третє, як було показано вище, в міжнародній практиці існують різні моделі імплементації Статуту МКС у національні законодавства, проте не можна сказати, що в Україні $€$ можливість вибрати будь-яку з них. Адже суворі принципи вітчизняної правової системи часом залишають єдиний шлях виконання імплементаційних процедур. Зокрема, принцип повної кодифікації кримінального законодавства вимагає, щоб зміни кримінально-правового характеру були включені до тексту Кримінального кодексу України, водночас міжнародно-правові норми слід трансформувати до кримінального й кримінально-процесуального законодавства відповідно до традицій вітчизняної юридичної техніки.

\section{Література}

1. Адельханян Р.А. Военные преступления в современном праве. Москва, 2006. 320 с.

2. Верле Г. Принципы международного криминального права : учебник. Москва, 2011. 910 с.

3. Гавердовский А.С. Имплементация норм международного права. Київ : Вища школа, 1980. 320 с.

4. Грін 0.0. Словник міжнародно-правових термінів / Укладач О.О.Грін. Ужгород : ПП Данило С.І., 2010. 500 c.

5. Документ C.I/4.1/1 було підготовлено МКЧХ для XXVI Міжнародної конференції Червоного Хреста і Червоного Півмісяця і представлений Раді делегатів Міжнародного руху Червоного Хреста і Червоного (28-30 листопада 1991 р.). Международное уголовное судопроизводство / И.Ю. Белый. Москва, 2007. 414 c.

6. Ежегодный доклад Amnesty International o правах человека в современном мире. 2015-2016 гг. URL: http://amnesty.org.ru/pdf/Annualreportbook15_16_ Russian.pdf.

7. За даними Хорватської неурядової правозахисної організації Documenta, основною метою якої $\epsilon$ моніторинг судових процесів над військовими злочинцями. URL: https://www.documenta.hr/hr/su\%C4 \%91enja-u-tijeku.

8. Йосипович И. Ответственность за военные преступления перед национальными судами в Хорватии. Международный журнал Красного креста. 2006. № 861. С. 179-207.

9. Каламкарян Р.А. Право международных договоров. Применение международных договоров во времени и пространстве. Москва, 2015. 277 с. 
10. Кибальник А.Г. Введение в международное уголовное право. Ставрополь, 2001. 203 с.

11. Кибальник А.Г. Современное международное уголовное право: понятие, задачи и принципы / под науч. ред. А.В. Наумова. Санкт-Петербург, 2003. 252 с.

12. Лобанов С.А. Международная уголовная ответственность за военные преступления : дисс. ... д-а юрид. наук : 12.00.10. Москва, 2018. 495 с. URL: https://www.dissercat.com/content/ mezhdunarodnaya-ugolovnaya-otvetstvennost-zavoennye-prestupleniya.

13. Международный уголовный суд: проблемы, дискуссии, поиск решений / под ред. Г.И. Богуша, Е.Н. Трикоз. Москва : Европейская Комиссия, 2008. 792 c.

14. Міжнародне право : підручник / під ред. М.Ю. Черкеса. Київ : Знання, 2000. 284 с.

15. Міжнародне публічне право : підручник / під ред. А.І. Дмітрієва, В.І. Муравйова. Київ : Юрінком Інтер, 2000. 640 c.

16. Нью-Йоркская Декларация о парламентском действии в поддержку МУС от 12 сентября 2003 года. URL: http://www.pgaction.org; http://www. victimstrustfund.org (Парламентский Пакет документов по Международному Уголовному Суду / [Парламентарии за Глобальное Действие]. http://www. pgaction.org/uploadedfiles/FINAL\%2OKIT(12).pdf).

17. Пособие по ратификации и имплементации Римского Статута. URL: http://www.icclr.law.ubc.ca; http://www. femida.info/12/muprirstatuta024.htm.

18. Правила процедуры и доказывания МТБЮ. United Nation. Rev. 37. 6 April 2006. URL: http:// www.icty.org/x/file/Legal\%20Library/Rules_ procedure_evidence/IT032_rev37_en.pdf.

19. Проблеми гармонізації законодавства України з міжнародним правом : матер. наук.-практ. конференції, м. Київ, жовтень 1998 р. Київ, 1998.

20. Римський статут Міжнародного кримінального суду від 17 липня 1998 р. База даних «Законодавство України». URL: https://zakon.rada.gov.ua/laws/ show/995_588.

21. Словарь международного права. Москва, 1986. 432 с.

22. Уголовный кодекс Республики Хорватия. URL: http://www.wipo.int/wipolex/ru/text.jsp?file_ id=301780.

23. Харитонова О.В. Римський статут і Міжнародний кримінальний суд в контексті сучасних світових та українських кримінально-правових наукових тенденцій. Український часопис міжнародного права. 2014. № 4/2014. С. 122-124.

24. Чубарєв В.Л. Парламентський контроль: практика України та міжнародний досвід. Проблеми державно-правової реформи в Україні : Збірник наукових праць. Вип. 3. Київ, 1997. С. 246.

25. Юридический энциклопедический словарь. Москва : ИНФРА-М, 1996. 368 с.

26. Юридична енциклопедія : В 6 т. / редкол. : Ю.С. Шемшученко (голова редкол.) та ін. Київ: «Укр. енцикл.». 1998. Т. 2 : Д-Й. 1999. 744 с.

27. Dictionary of Language. New York, 1968.

28. International Criminal Court: Guidelines for effective implementation of the Rome Statute. Amnesty International (AI Index: IOR 40/013/2004). September 1, 2004. URL: http://web.amnesty.org/library/ print/ENGIOR400132004.

29. International Criminal Court: Manual for the Ratification and Implementation of the Rome Statute. The International Centre for Criminal Law Reform and Criminal Justice Policy. Third Edition. Vancouver, March 2008. 120 p.

30. International Criminal Court: The failure of states to enact effective implementing legislation. International Amnesty (IOR 40/019/2004). September 1, 2004. (Or: The failure of states to implement the Rome Statute effectively (AI Index: IOR 40/015/2004). August, 2004) URL: http://web.amnesty.org/library/ Index/ENGIOR400192004?open\&of=ENG-385.

31. Making the International Criminal Court work: A Handbook for Implementing the Rome Statute. Human Rights Watch. September 2001. Vol. 13. №. 4 (G). 32 p.

32. The International Criminal Court: Summary Checklist for Effective Implementation. Amnesty International. URL: http://web.amnesty.org/en/library/ info/IOR40/015/2000/en.

33. Universal Jurisdiction: 14 Principles for the effective exercise of universal jurisdiction. Amnesty International (Al Index: IOR 53/001/99). May 1999. URL: http:// www.amnesty.org/en/library/info/IOR53/001/1999.

34. Universal Jurisdiction: The duty of states to enact and implement legislation. Amnesty International (AI Index: IOR 53/002- 018/2001). September, 2001. URL: https://www.amnesty.org/en/documents/ IOR53/017/2001/en/.

35. Volkerstrafgesetzbuch (VStGB). In der Fassung vom 26. Juni 2002. Fundstelle. BGB. 2002. № 1. URL: https: / /www.gesetze-im-internet.de/vstgb/ BJNR225410002.html

36. Websters Third New International Dictionary, Cambridge, 1966. 3135 p.

Пилипенко В. П., кандидат юридичних наук, заслужений юрист України, член $є в$ вопейської комісії «3а демократію через право» (2013-2017рр.), адвокат 